\title{
Taxonomic Study of Xenorhabdus, a Genus of Bacteria Symbiotically Associated with Insect Pathogenic Nematodes
}

\author{
RAYMOND J. AKHURST \\ Division of Entomology, Commonwealth Scientific and Industrial Research Organization, Hobart 7000, \\ Tasmania, Australia
}

\begin{abstract}
The taxonomy of the bacteria symbiotically associated with the insect-pathogenic nematodes Neoaplectana and Heterorhabditis was examined. The bacteria studied were isolated from 33 populations obtained from Australasia, Europe, and the United States. The symbionts of all species of Neoaplectana and Heterorhabditis examined were members of the genus Xenorhabdus, but they differed in several respects from the description of the genus Xenorhabdus, including the guanine-plus-cytosine content of the deoxyriboneucleic acid and the production of acid from carbohydrates. All bacteria isolated from Heterorhabditis spp. were identified as members of Xenorhabdus luminescens. The bacteria isolated from one Neoaplectana species were similar and were distinguishable from the bacteria isolated from other Neoaplectana species. The following three subspecies of Xenorhabdus nematophilus are proposed: Xenorhabdus nematophilus subsp. nematophilus (bacteria symbiotic with Neoaplectana feltiae [ = Neoaplectana carpocapsae]; type strain ATCC 19061), Xenorhabdus nematophilus subsp. bovienii (bacteria symbiotic with Neoaplectana bibionis; type strain, UQM $2210^{\mathrm{T}}$ ), and Xenorhabdus nematophilus subsp. poinarii (bacteria symbiotic with Neoaplectana glaseri; type strain, UQM 2216). These subspecies vary in host nematode, pigmentation, maximum temperature for growth, responses to tests for phenylalanine deaminase by secondary-form isolates and for lipase (Tween $\mathbf{8 0}$ test) and lecithinase by primary-form isolates, and coloration of primary-form isolates on MacConkey agar and media containing bromthymol blue.
\end{abstract}

Specific associations between insect-pathogenic nematodes and bacteria have been described for two genera of nematodes. An association between Neoaplectana and bacteria was suggested by Bovien (5) for Neoaplectana bibionis Bovien and was demonstrated for $\mathrm{NeO}$ aplectana feltiae Filipjev (synonym, Neoaplectana carpocapsae [24]) and for Neoaplectana glaseri Steiner by Dutky (S. R. Dutky, Ph.D. thesis, Rutgers University, New Brunswick, N.J., 1937) and by Poinar and Brooks (16), respectively. Poinar (15) and Khan et al. (12) showed that Heterorhabditis spp. are specifically associated with bacteria.

The infective stages of Neoaplectana and Heterorhabditis are free-living, nonfeeding juveniles which carry the symbiotic bacteria monoxenically in their guts. After entering an insect host, a nematode moves to the haemocoel, where it releases symbiotic bacteria. The bacteria proliferate, kill the insect, and establish suitable conditions for reproduction of the nematodes by providing nutrients and inhibiting the growth of other microorganisms (18). In due course, a new generation of infective-stage nematodes is produced, and these nematodes pro- vide the means for the symbiotic bacteria to reach new hosts.

Poinar and Thomas (17) described the bacterial symbiont of $N$. feltiae strain DD136 as a new species, "Achromobacter nematophilus." However, when the genus Achromobacter was rejected (6), "A. nematophilus" could not be assigned to any accepted genus. The bacterial symbionts of two Heterorhabditis species were characterized, but not named, by Poinar et al. (19) and Khan and Brooks (11). Subsequently, Thomas and Poinar (25) erected the new genus Xenorhabdus within the family Enterobacteriaceae, to accommodate the symbionts of Neoaplectana and Heterorhabditis. These authors described the following two species in this genus: Xenorhabdus nematophilus (Poinar and Thomas) Thomas and Poinar and Xenorhabdus luminescens Thomas and Poinar. These two species are symbiotic with Neoaplectana spp. and Heterorhabditis spp., respectively.

Akhurst (1) found that bacterial symbionts of Neoaplectana and Heterorhabditis produced two colony forms. In general, only one form, designated the primary form, could be isolated from infective-stage nematodes. The secondary 
form was isolated from infected insects, from monoxenic in vitro cultures of nematodes and symbiotic bacteria, or from pure cultures of bacterium. The primary form was unstable and was readily converted to the secondary form, which was usually stable. The two forms of $X$. nematophilus were equally pathogenic but differed in their reactions to tests for phenylalanine deaminase, lipase, and the absorption of bromthymol blue from agar media. In in vivo and in vitro cultures the nematodes reproduced more rapidly and more prolifically with the primary form of their Xenorhabdus sp. symbiont than with the secondary form.

In this paper I present the results of a taxonomic study of the bacteria isolated from several species of Neoaplectana and Heterorhabditis. Three subspecies of $X$. nematophilus are proposed.

\section{MATERIALS AND METHODS}

Bacterial strains. The sources of the nematodes from which the bacteria were isolated are listed in Table 1. Nematode species belonging to the genus Neoaplectana were identified by cross-breeding (2).

With two exceptions, the primary forms of the bacteria were isolated directly from the infective stages of the nematodes by maceration (1). The symbiont of $N$. feltiae strain DD136 was obtained from the American Type Culture Collection (ATCC 19061 ${ }^{\mathrm{T}}$ ). The secondary forms of Xenorhabdus isolates were obtained either from infected Galleria mellonella (L.) larvae or from monoxenic cultures on artificial media.

Stock cultures of the bacteria were maintained on the yeast extract salts agar of Dye (9) $(0.5 \mathrm{~g}$ of $\mathrm{NH}_{4} \mathrm{H}_{2} \mathrm{PO}_{4}, 0.5 \mathrm{~g}$ of $\mathrm{K}_{2} \mathrm{HPO}_{4}, 0.2 \mathrm{~g}$ of $\mathrm{MgSO}_{4} \cdot 7 \mathrm{H}_{2} \mathrm{O}$, $5.0 \mathrm{~g}$ of $\mathrm{NaCl}, 5.0 \mathrm{~g}$ of yeast extract, and $12 \mathrm{~g}$ of purified agar in 1 liter of water) at $12^{\circ} \mathrm{C}$ and subcultured monthly.

Methods. All tests except those requiring shaking were conducted at $28^{\circ} \mathrm{C}$; the tests requiring shaking were conducted at $25^{\circ} \mathrm{C}$. In general, test media were inoculated by using cells from 1- to 6-day-old YDC agar $(10 \mathrm{~g}$ of yeast extract, $5 \mathrm{~g}$ of dextrose, $20 \mathrm{~g}$ of $\mathrm{CaCO}_{3}$, and $15 \mathrm{~g}$ of agar in 1 liter of water) (9) cultures, which produced considerably higher numbers of cells than cultures in nutrient agar (NA; Difco Laboratories) or yeast extract salts agar. For tests in which growth was examined, the medium was inoculated with a loopful of an aqueous suspension of cells from a YDC agar culture.

Average cell size was estimated by measuring 50 cells from 24-h-old yeast extract salts broth (YSB; yeast extract salts agar without agar) cultures in wet mounts. Motility was assessed by examining hanging drops of 24-h-old YSB cultures, and the flagellum position was determined by transmission electron microscopy after negatively staining cells from 24-h-old YSB cultures. Air-dried films of 24-h-old YSB cultures were stained for the Gram reaction and were checked by treating a heavy suspension of cells from a YSB culture with $10 \%$ sodium dodecyl sulfate (10).

Colony and cultural characteristics were studied on NA, tergitol-7 agar (Difco) supplemented with triphen- yltetrazolium chloride (TTC), MacConkey agar (Difco), Simmons citrate agar (Difco), and triple sugar iron agar (Difco). Pigmentation of colonies was recorded after growth on NA and YDC agar.

Catalase activity was tested by flooding 24-h-old NA cultures with $10 \%$ ( $\mathrm{vol} / \mathrm{vol}$ ) hydrogen peroxide and also by placing a loopful of cells from a 24 -h-old NA culture into a drop of $10 \%(\mathrm{vol} / \mathrm{vol})$ hydrogen peroxide on a glass slide. These tests were repeated with cultures grown on the GYCA medium of Dye (9) (5 g of glucose, $5 \mathrm{~g}$ of yeast extract, $40 \mathrm{~g}$ of $\mathrm{CaCO}_{3}$, and $15 \mathrm{~g}$ of agar in 1 liter of water). The following tests were conducted as described by Dye (9): oxidation-fermentation, oxidase, hydrolysis of starch and esculin, methyl red, nitrate reduction, urease, $\mathrm{KCN}$ tolerance, maximum temperature for growth, reducing substances from sucrose, growth factor requirements, and utilization of organic acids (using OY medium). Gluconate utilization was also tested by the method of Shaw and Clarke (22). Acetoin production in shake cultures was tested in the acetoin medium of Dye (9) and in MR-VP medium (Difco) after 2 and 5 days of incubation, as described by Dye (9). Samples from shaken cultures in the indole medium of Dye (9) were tested after 2 and 5 days with Kovac reagent and also with Ehrlich reagent after xylene was added. Casein hydrolysis was tested on Dye OY agar (9) containing $10 \%$ ( $\mathrm{vol} / \mathrm{vol}$ ) skim milk.

The tyrosinase and chitinase tests used were those used by Khan and Brooks (11). Lecithinase and lipase were tested on yeast extract salts agar containing 5\% (vol/vol) fresh egg yolk emulsion (20\% [wt/wt]) egg yolk in distilled water) and on tryptone agar $(11.0 \mathrm{~g}$ of tryptone and $12.0 \mathrm{~g}$ of agar in 1 liter of distilled water) containing $5 \%(\mathrm{vol} / \mathrm{vol})$ fresh egg yolk emulsion. Lipase activity was also assessed on the medium of Sierra (23) with the Tween 80 concentration reduced to $0.2 \%$ ( $\mathrm{vol} / \mathrm{vol}$ ) to allow more vigorous growth. Gelatin hydrolysis was tested in nutrient gelatin, and protease activity was tested on Loeffler blood serum and egg albumin agar (Trypticase soy agar supplemented with $0.11 \%[\mathrm{vol} / \mathrm{vol}] \mathrm{CaCl}_{2}$ and $1.25 \%[\mathrm{vol} / \mathrm{vol}] \mathrm{egg}$ albu$\min )$.

The tests of Moeller (13) for arginine dihydrolase and lysine, ornithine, and glutamic acid decarboxylases were used. Deoxyribonuclease activity was tested as described previously (8), cytochrome oxidase was tested by the method of Schaeffer (20), and peroxidase was tested by the method of Anderson (3). The test for phosphatase was conducted on phenolphthalein phosphate agar as described by Cowan and Steel (7). Cultures on phenylalanine agar (Difco) were tested with freshly prepared reagents (8) after 2,5 , and 7 days to assess phenylalanine deaminase activity.

The production of acid from all carbon sources except esculin was assessed in $1 \%$ (wt/vol) peptone water containing bromcresol purple and $1 \%(\mathrm{wt} / \mathrm{vol})$ carbon source; esculin was tested at a concentration of $0.1 \%$ (wt/vol). Esculin, inulin, and salicin were tyndallized in the medium; all other carbon sources were filter sterilized and added to the cooled, autoclaved basal medium.

Bioluminescence was determined by examining 48h-old NA cultures for $10 \mathrm{~min}$ in total darkness.

The buoyant densities of the deoxyribonucleic acids (DNAs) of seven isolates were determined jointly by G. Skyring and E. Dennis, using ultracentrifugation 
TABLE 1. Sources of the bacterial isolates used in this study

\begin{tabular}{|c|c|c|c|c|}
\hline Group & Isolate & Form(s) ${ }^{a}$ & Nematode & Source of nematode ${ }^{b}$ \\
\hline \multirow[t]{7}{*}{$\mathbf{I}$} & A24 & $\mathbf{P}$ & $\begin{array}{l}\text { N. feltiae strain } \\
\text { Agriotos }^{c}\end{array}$ & Poinar \\
\hline & A25 & $S$ & $\begin{array}{l}\text { N. feltiae strain } \\
\text { Agriotos }\end{array}$ & Poinar \\
\hline & $\mathrm{AN} / 5$ & $\mathbf{P}$ & $\begin{array}{l}N . \text { feltiae strain } \\
\text { DD136 }\end{array}$ & ATCC 19061 \\
\hline & N55 & $\mathbf{P}$ & N. feltiae & $\begin{array}{l}\text { Murrumbateman, New South } \\
\text { Wales, Australia }^{d}\end{array}$ \\
\hline & $\mathrm{Pi}$ & $\mathbf{P}$ & $\begin{array}{l}\text { N. feltiae strain } \\
\text { Pieridarum }\end{array}$ & Stanuszek \\
\hline & TN6 & $P+S$ & $\begin{array}{l}\text { N. feltiae strain } \\
\text { Nelson }\end{array}$ & $\begin{array}{l}\text { Vespula sp., Hobart, Tasmania, } \\
\text { Australia }\end{array}$ \\
\hline & TP7 & $\mathbf{P}$ & N. feltiae & Powranna, Tasmania, Australia ${ }^{d}$ \\
\hline \multirow[t]{15}{*}{ II } & NBC & $\mathbf{P}$ & N. bibionis & Mrácek \\
\hline & N51 & $\mathrm{P}$ & N. bibionis & $\begin{array}{l}\text { Murrumbateman, New South } \\
\text { Wales, Australia }{ }^{d}\end{array}$ \\
\hline & $\mathrm{NZ}$ & $\mathrm{P}$ & $N$. bibionis & Wouts \\
\hline & $\mathrm{T} 228$ & $\mathrm{P}$ & N. bibionis & Dover, Tasmania, Australia ${ }^{d}$ \\
\hline & T231 & $\mathbf{P}$ & N. bibionis & $\begin{array}{l}\text { Risdon Vale, Tasmania, } \\
\text { Australia }^{d}\end{array}$ \\
\hline & T268 & $\mathbf{P}$ & N. bibionis & Dover, Tasmania, Australia ${ }^{d}$ \\
\hline & T292 & $\mathbf{P}$ & N. bibionis & Nive River, Tasmania, Australia ${ }^{d}$ \\
\hline & T298 & $\mathrm{P}$ & N. bibionis & Plenty, Tasmania, Australia ${ }^{d}$ \\
\hline & $\mathrm{T} 302$ & $\mathbf{P}$ & N. bibionis & $\begin{array}{l}\text { Bruny Island, Tasmania, } \\
\text { Australia }^{d}\end{array}$ \\
\hline & $\mathrm{T} 307$ & $\mathbf{P}$ & N. bibionis & $\begin{array}{l}\text { Bruny Island, Tasmania, } \\
\text { Australia }^{d}\end{array}$ \\
\hline & T319 & $\mathbf{P}$ & N. bibionis & $\begin{array}{l}\text { Mt. Wellington, Tasmania, } \\
\text { Australia }^{d}\end{array}$ \\
\hline & $\mathrm{T} 335 / 1$ & $\mathbf{P}$ & N. bibionis & $\begin{array}{l}\text { Otiorhynchus sulcatus, Nicholls } \\
\text { Rivulet, Tasmania, Australia }\end{array}$ \\
\hline & $\mathrm{T} 335 / 2$ & $\mathbf{S}$ & N. bibionis & $\begin{array}{l}\text { Otiorhynchus sulcatus, Nicholls } \\
\text { Rivulet, Tasmania, Australia }\end{array}$ \\
\hline & V1 & $\mathbf{P}$ & N. bibionis & Sexton \\
\hline & V3 & $\mathbf{P}$ & N. bibionis & Sexton \\
\hline \multirow[t]{2}{*}{ III } & $\mathrm{G} / 1$ & $\mathrm{P}$ & N. glaseri & Kaya \\
\hline & $\mathrm{G} / 2$ & $\mathbf{S}$ & N. glaseri & Kaya \\
\hline \multirow[t]{4}{*}{ IV } & N37 & $?$ & $\begin{array}{l}\text { Neoaplectana sp. } \\
\mathrm{N} \text { (undescribed) }\end{array}$ & $\begin{array}{l}\text { Coonabarabran, New South } \\
\text { Wales, Australia }{ }^{d}\end{array}$ \\
\hline & T80 & $?$ & $\begin{array}{l}\text { Neoaplectana sp. } \\
\text { M (undescribed) }\end{array}$ & Tonganah, Tasmania, Australia ${ }^{d}$ \\
\hline & $\mathrm{T} 171$ & $?$ & $\begin{array}{l}\text { Neoaplectana sp. } \\
\mathrm{M} \text { (undescribed) }\end{array}$ & Cleveland, Tasmania, Australia ${ }^{d}$ \\
\hline & T300 & $?$ & $\begin{array}{l}\text { Neoaplectana sp. } \\
\mathrm{M} \text { (undescribed) }\end{array}$ & $\begin{array}{l}\text { Bruny Island, Tasmania, } \\
\text { Australia }^{d}\end{array}$ \\
\hline \multirow[t]{10}{*}{ V } & B & $\mathbf{P}$ & $\begin{array}{l}\text { Heterorhabditis } \\
\text { bacteriophora }\end{array}$ & Wouts \\
\hline & $\mathrm{C}$ & $\mathbf{P}$ & $\begin{array}{l}\text { Heterorhabditis } \\
\text { heliothidis }\end{array}$ & Wouts \\
\hline & D & $\mathbf{P}$ & Heterorhabditis sp. & $\begin{array}{l}\text { Darwin, Northern Territory, } \\
\text { Australia }^{d}\end{array}$ \\
\hline & $\mathrm{HP} / 1$ & $\mathbf{P}$ & Heterorhabditis sp. & Stanuszek \\
\hline & $\mathrm{HP} / 2$ & $\mathbf{S}$ & Heterorhabditis sp. & Stanuszek \\
\hline & $\mathrm{NZH}$ & $\mathbf{P}$ & H. heliothidis & Wouts \\
\hline & $\mathrm{T} 280 / 1$ & $\mathbf{P}$ & Heterorhabditis sp. & Wynyard, Tasmania, Australia ${ }^{d}$ \\
\hline & $\mathrm{T} 280 / 2$ & $\mathbf{S}$ & Heterorhabditis sp. & Wynyard, Tasmania, Australia ${ }^{d}$ \\
\hline & T301 & $\mathbf{P}$ & Heterorhabditis sp. & $\begin{array}{l}\text { Bruny Island, Tasmania, } \\
\text { Australiad }^{d}\end{array}$ \\
\hline & $\mathrm{T} 310$ & $\mathbf{P}$ & Heterorhabditis sp. & Sandy Bay, Tasmania, Australia ${ }^{d}$ \\
\hline
\end{tabular}

${ }^{a} \mathbf{P}$, Primary form; $\mathrm{S}$, secondary form.

${ }^{b}$ Poinar, G. O. Poinar, University of California, Berkeley; Stanuszek, S. Stanuszek, Institute of Ecology, Warsaw, Poland; Mráček, Z. Mrácek, Entomological Institute, CSAV, České Budějovice, Czechoslovakia; Wouts, W. Wouts, DSIR, Department of Scientific and Industrial Research, New Zealand; Sexton, S. Sexton, Plant Research Institute, Burnley, Victoria, Australia; Kaya, H. Kaya, University of California, Davis.

${ }^{c} N$. feltiae $=N$. carpocapsae.

${ }^{d}$ Isolated from soil by the method of Bedding and Akhurst (4). 


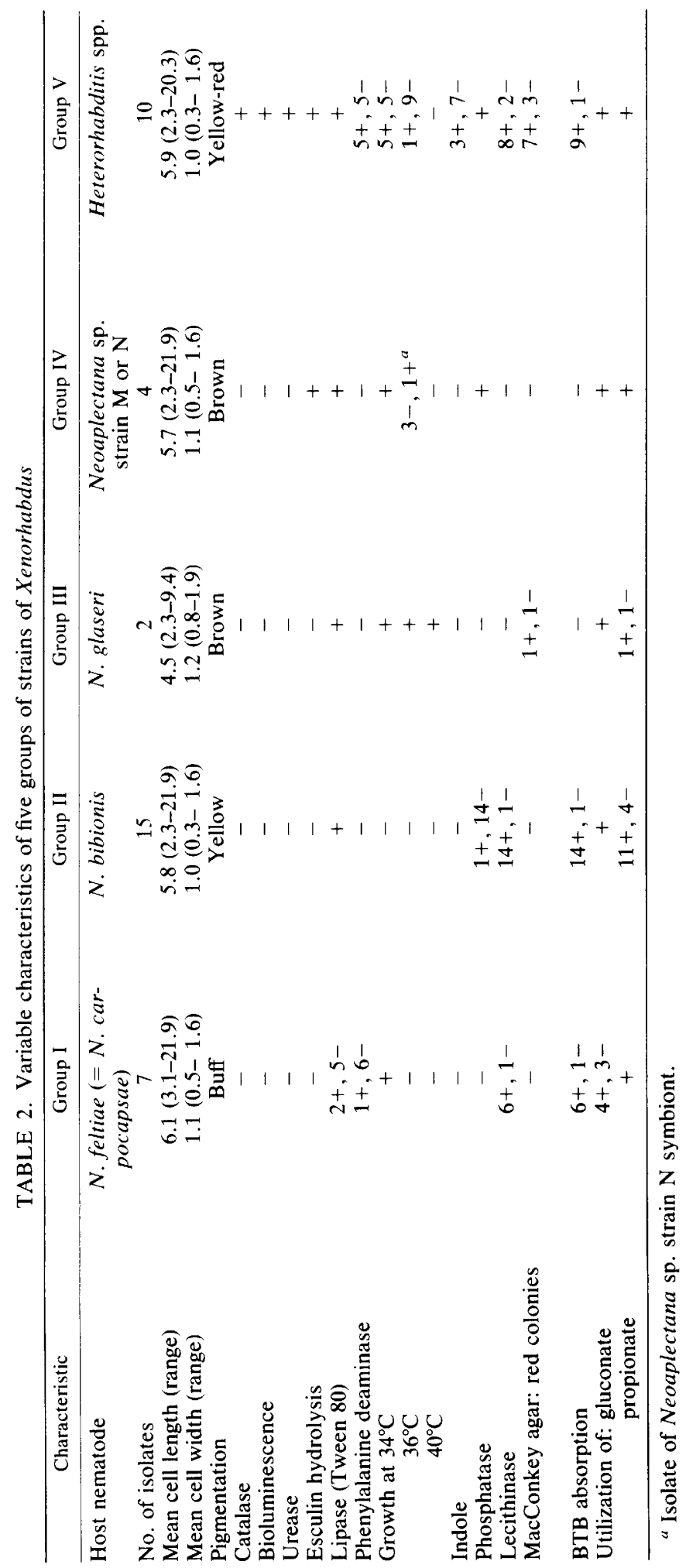


and Micrococcus luteus DNA as the standard. The guanine-plus-cytosine $(G+C)$ contents of the DNAs were then calculated by using the formula of Schildkraut et al (21).

\section{RESULTS}

Colonies formed on NA by the primary forms of the bacteria symbiotic with Neoaplectana spp. (groups I through IV) were convex, circular with slightly irregular margins, 1.5 to $2.0 \mathrm{~mm}$ in diameter after 4 days, and slightly granular; pigmentation varied with the nematode species (Table 2). The secondary-form colonies of these bacteria were similar to the primary-form colonies but somewhat flatter, wider (diameter, 2.5 to $3.5 \mathrm{~mm}$ ), and more lightly pigmented. On tergitol-7 medium containing TTC, the primary forms of group I and group II bacteria produced blue and green colonies, respectively, surrounded by decolorized zones after 3 to 5 days. Secondary-form colonies did not absorb bromthymol blue; these colonies were red. Neither form of the group III bacterium absorbed bromthymol blue, and both forms produced red colonies.

On NA, the primary forms of all bacteria symbiotic with Heterorhabditis spp. (group V) except isolate $\mathrm{T} 280 / 1$ formed colonies that were mucoid, convex, circular with slightly irregular margins, and $3 \mathrm{~mm}$ in diameter after 4 days; isolate $\mathrm{T} 280 / 1$ primary-form colonies were slightly flattened and $4 \mathrm{~mm}$ in diameter. The pigmentation of the colonies of some isolates varied with time; all were yellow after 2 days and then some progressed through orange to red or through light brown to pink. The secondaryform colonies of these bacteria were much flatter and wider ( $4.5 \mathrm{~mm}$ after 4 days) than the primary-form colonies, had more irregular margins, and were not mucoid. Two of the secondary-form isolates were further differentiated as follows: isolate $\mathrm{T} 280 / 2$ formed rough colonies and isolate $\mathrm{HP} / 2$ formed yellow colonies, whereas isolate $T 280 / 1$ formed smooth colonies and isolate $\mathrm{HP} / 1$ formed orange colonies. Colonies of the primary form on tergitol-7 medium containing TTC were green with orangish brown centers and were surrounded by clearing zones diffused with pigment. None of the secondaryform colonies except those of isolate T280/2 absorbed bromthymol blue from tergitol-7 medium containing TTC.

The results of these tests are summarized in Tables 2 through 5 .

\section{DISCUSSION}

All of the symbionts of Neoaplectana and Heterorhabditis examined in this and previous studies should be grouped in the same genus. However, the results of a previous study (1) and
TABLE 3. Characteristics common to all isolates ${ }^{a}$

\begin{tabular}{|c|c|}
\hline Test & Result \\
\hline Gram stain . & - \\
\hline 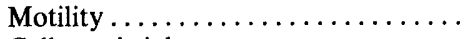 & + \\
\hline Cells peritrichous $\ldots \ldots \ldots \ldots \ldots$ & + \\
\hline Oxidase.$\ldots \ldots \ldots \ldots \ldots \ldots \ldots$ & - \\
\hline Cytochrome oxidase........... & - \\
\hline Peroxidase $\ldots \ldots \ldots \ldots \ldots \ldots \ldots$ & - \\
\hline Hugh and Leifson (open tube) ...... & + \\
\hline Hugh and Leifson (closed tube)..... & + \\
\hline Gelatin liquefaction ........... & + \\
\hline Casein hydrolysis $\ldots \ldots \ldots \ldots \ldots$ & + \\
\hline Deoxyribonuclease ............. & + \\
\hline $\mathrm{KCN} \ldots \ldots \ldots \ldots \ldots \ldots \ldots \ldots \ldots \ldots \ldots$ & + \\
\hline Reducing compounds from sucrose. & - \\
\hline Lipase (egg yolk agar) .......... & + \\
\hline Potato starch hydrolysis ......... & - \\
\hline Soluble starch hydrolysis . . . . . . . & - \\
\hline Acetoin $\ldots \ldots \ldots \ldots \ldots \ldots \ldots \ldots$ & - \\
\hline Methyl red $\ldots \ldots \ldots \ldots \ldots \ldots$ & - \\
\hline Nitrate reduction. ............ & - \\
\hline 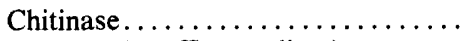 & - \\
\hline Protease (Loeffler medium). . . . . . . . & - \\
\hline Protease (egg albumin). .......... & - \\
\hline Tyrosinase $\ldots \ldots \ldots \ldots \ldots \ldots \ldots$ & - \\
\hline Arginine dihydrolase $\ldots \ldots \ldots \ldots \ldots$ & - \\
\hline Lysine decarboxylase $\ldots \ldots \ldots \ldots$ & - \\
\hline Ornithine decarboxylase $\ldots \ldots \ldots \ldots$ & - \\
\hline Glutamic acid decarboxylase ...... & - \\
\hline TSI (slope, butt, $\mathrm{H}_{2} \mathrm{~S}$ ) $\ldots \ldots \ldots \ldots$ & Alkaline/acid/- \\
\hline Utilization of acetate in OY medium & + \\
\hline Utilization of benzoate $\ldots \ldots \ldots \ldots$ & - \\
\hline Utilization of citrate $\ldots \ldots \ldots \ldots \ldots$ & + \\
\hline Utilization of formate $\ldots \ldots \ldots \ldots$ & + \\
\hline Utilization of fumarate..$\ldots \ldots \ldots$ & + \\
\hline Utilization of lactate............ & + \\
\hline Utilization of malate. ........... & + \\
\hline Utilization of malonate $\ldots \ldots \ldots \ldots$ & - \\
\hline Utilization of oxalate $\ldots \ldots \ldots \ldots$ & - \\
\hline Utilization of succinate $\ldots \ldots \ldots \ldots$ & + \\
\hline Utilization of tartrate . . . . . . . . & - \\
\hline $\begin{array}{l}\text { Gluconate utilization } . . . . \cdots \ldots \ldots \ldots \\
\text { (Shaw-Clark medium) }\end{array}$ & - \\
\hline Growth on MacConkey agar ...... & + \\
\hline
\end{tabular}

${ }^{a}$ In addition, the cells of all isolates were rod shaped.

of this study indicate that the description of the genus Xenorhabdus may require revision. The production of two colony forms is characteristic of members of this genus. Although group IV bacteria were available only in one form (probably secondary), subsequent isolations of bacteria from new populations of Neoaplectana sp. strain $\mathbf{M}$ have yielded a Xenorhabdus sp. which occurs in two forms (Akhurst, unpublished data). The dimorphic characteristic should be included in the definition of the genus Xenorhabdus. In this study, the bacteria produced acid from some but not all carbohydrates tested, and none of the isolates produced glutamic acid decarboxylase. Some isolates produced phenyl- 
TABLE 4. Production of acid from carbon sources by Xenorhabdus spp.

\begin{tabular}{|c|c|c|c|c|c|}
\hline Carbon source & Group I & Group II & Group III & Group IV & Group V \\
\hline Adonitol & - & - & - & - & - \\
\hline Arabinose & - & - & - & - & - \\
\hline Cellobiose & $3 \pm, 4-$ & $6 \pm, 9-$ & $1 \pm, 1-$ & $3 \pm, 1-$ & $4 \pm, 6-$ \\
\hline Dextrin & $+w$ & $+w$ & $+w$ & $+w$ & $+w$ \\
\hline Esculin & - & - & - & - & - \\
\hline Fructose & + & $14+, 1+w$ & + & + & + \\
\hline Galactose & - & - & - & - & - \\
\hline Glucose & + & + & + & + & + \\
\hline Glycerol & - & $1+w, 9 \pm, 5-$ & $+w$ & $1+w, 3-$ & - \\
\hline Inositol & $4 \pm, 3-$ & $11 \pm, 4-$ & $1 \pm, 1-$ & \pm & $8 \pm, 2-$ \\
\hline Inulin & - & - & - & - & - \\
\hline Lactose & - & - & - & - & - \\
\hline Maltose & $+w$ & $+w$ & $1+, 1+w$ & $2+, 2+w$ & $1+, 9+w$ \\
\hline Mannitol & - & - & - & - & - \\
\hline Mannose & + & + & $1+, 1+w$ & + & + \\
\hline Melezitose & $6+w, 1 \pm$ & $13+w, 2 \pm$ & $1+w, 1 \pm$ & $+w$ & $9+w, 1 \pm$ \\
\hline Melibiose & - & - & - & - & - \\
\hline$\alpha$-Methyl glucoside & - & $3 \pm, 12-$ & - & - & - \\
\hline$\beta$-Methyl glucoside & - & - & - & - & - \\
\hline Raffinose & - & - & - & - & - \\
\hline Rhamnose & - & - & - & - & - \\
\hline Ribose & $+w$ & $+w$ & $+w$ & $+w$ & $+w$ \\
\hline Saccharose & - & $3 \pm, 12-$ & - & - & $1 \pm, 9-$ \\
\hline Salicin & - & - & - & $3+w, 1-$ & $2 \pm, 8-$ \\
\hline Sorbitol & - & $3 \pm, 12-$ & - & - & $1 \pm, 9-$ \\
\hline Sorbose & - & - & - & - & - \\
\hline Sucrose & $2 \pm, 5-$ & $2 \pm, 13-$ & $1 \pm, 1-$ & - & $1 \pm, 9-$ \\
\hline Trehalose & $+w$ & $+w$ & $+w$ & $1+, 3+w$ & $9+w, 1 \pm$ \\
\hline Xylose & $3 \pm, 4-$ & $5 \pm, 10-$ & - & $1 \pm, 3-$ & $1 \pm, 9-$ \\
\hline
\end{tabular}

alanine deaminase or urease or both, and all produced lipase on egg yolk agar. Some did not form blue colonies on tergitol-7 medium containing TTC. The $\mathrm{G}+\mathrm{C}$ contents of the DNAs were outside the range reported by Thomas and Poinar for Xenorhabdus (25).

Differences between my results and the results of Thomas and Poinar (25) may be due in part to differences in the methods used. In this study bromcresol purple was used to determine acid production from carbohydrates because the bacteria produced enough acid from the basal medium to affect bromthymol blue. Phenylalanine deaminase production was tested after 5 and 7 days, as well as after 2 days as prescribed in the Difco Supplementary Literature (8) because results obtained after 2 days were inconsistent. Citrate utilization was tested on OY agar rather than on Simmons citrate agar because the isolates grew poorly on the latter. Lipase activity was tested with fresh egg yolk emulsion rather than with egg yolk extract. The methods used in this study to detect urease and the utilization of organic acids may also have been different from

TABLE 5. DNA base ratios of some Xenorhabdus isolates

\begin{tabular}{|c|c|c|c|c|}
\hline $\begin{array}{l}\text { Bacterial } \\
\text { isolate }\end{array}$ & Group & Nematode species & $\begin{array}{l}\text { Bouyant } \\
\text { density } \\
\left(\mathrm{g} / \mathrm{cm}^{3}\right)\end{array}$ & $\begin{array}{c}\mathrm{G}+\mathrm{C} \text { content } \\
(\mathrm{mol} \%)\end{array}$ \\
\hline M. luteus ${ }^{a}$ & & & 1.731 & 72.4 \\
\hline A24 & I & $\begin{array}{l}\text { N. feltiae } \\
\quad(=N . \text { carpocapsae })\end{array}$ & 1.707 & 48.0 \\
\hline A25 & I & $\begin{array}{l}\text { N. feltiae } \\
\quad(=N . \text { carpocapsae })\end{array}$ & 1.707 & 48.0 \\
\hline T231 & II & N. bibionis & 1.706 & 46.9 \\
\hline $\mathrm{G} / 2$ & III & N. glaseri & 1.708 & 49.0 \\
\hline N37 & IV & Neoaplectana sp. strain $\mathbf{N}$ & 1.709 & 50.0 \\
\hline T171 & IV & Neoaplectana sp. strain $\mathbf{M}$ & 1.708 & 49.0 \\
\hline T310 & V & Heterorhabditis sp. & 1.707 & 48.0 \\
\hline
\end{tabular}

\footnotetext{
${ }^{a}$ Included as a standard.
} 


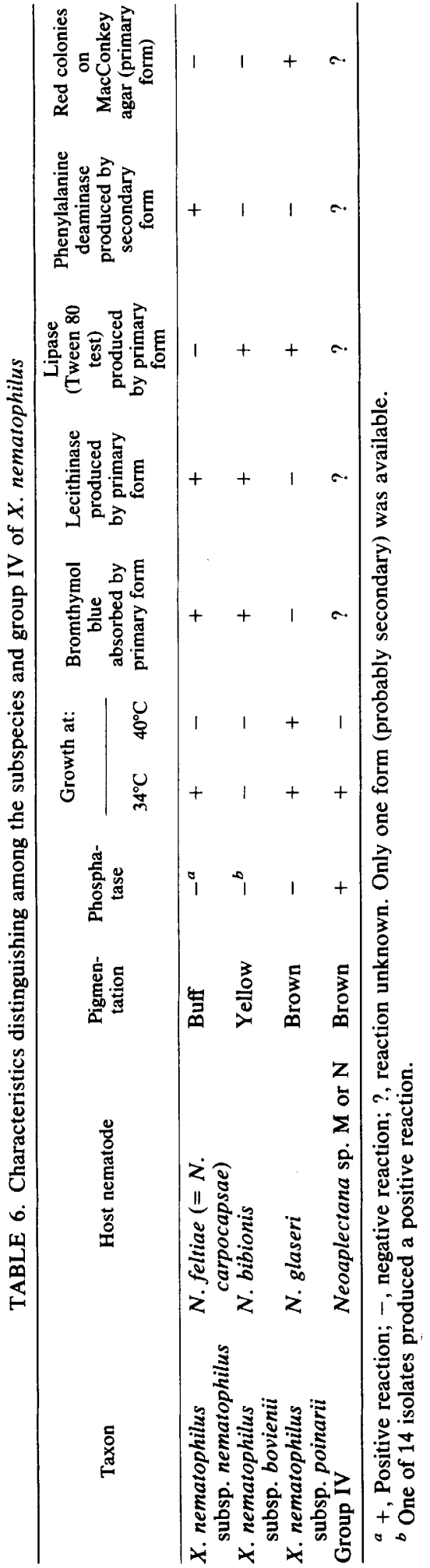

those of Thomas and Poinar (25), which were not specified.

There must be some doubt about the range of the $\mathrm{G}+\mathrm{C}$ contents of the DNAs of Xenorhabdus spp. In describing the genus, Thomas and Poinar (25) give values of 43 to $44 \mathrm{~mol} \%$ for nine isolates, whereas Khan and Brooks (11) recorded a value of $45.6 \mathrm{~mol} \%$ for one of those isolates and in this study values ranged from 46.9 to 50.0 mol\% for another seven isolates. Although these differences in $\mathrm{G}+\mathrm{C}$ content of DNA may only reflect differences in methods of determination, this part of the genus description obviously requires more attention.

Thomas and Poinar (25) listed only two species in the genus Xenorhabdus, $X$. nematophilus (the symbionts of $N$. feltiae, Neoaplectana bibionis, and some unidentified Neoaplectana spp.) and $X$. luminescens (the symbionts of Heterorhabditis spp.). In this study I show that the bacterial symbionts of any one species of Neoaplectana are consistently similar and are distinguishable from the bacteria symbiotic with any other species. Thomas and Poinar (25) did not distinguish among the symbionts of their various Neoaplectana spp. However, since these authors had only a small number of isolates, separation would not have been justified. The characteristics that distinguish these groups of bacteria (groups I through IV) from each other are few (Table 6) and probably are insufficient to warrant division of the groups into separate species. Moreover, none of the bacteria in groups I through IV showed catalase or peroxidase activity, which is unusual in facultatively anaerobic bacteria. Since the absence of such activity has not been shown to be required in the interaction between nematodes and bacteria it must be considered a good argument for classifying groups I through IV as a single species, $X$. nematophilus. However, the groups should be distinguished taxonomically because, except for group IV, each bacterial group is found only in association with one nematode species, and although the infective stage of a strain of Neoaplectana transmits bacteria belonging to the same group as the natural symbiont, only a very small proportion of infectivestage nematodes can transmit bacteria from another group (Akhurst, unpublished data). Since these groups can also be identified by other characteristics (Table 6), they should be considered subspecies. It would be premature to describe a subspecies for group IV since it is very likely that the primary form of these bacteria has not been studied. The proposed subspecies, whose differentiating characteristics are shown in Table 6, are as follows: Xenorhabdus nematophilus subsp. nematophilus for bacteria symbiotic with $N$. feltiae (type strain, ATCC 
19061); Xenorhabdus nematophilus subsp. bovienii (bo.vi.en'i.i. M.L. gen. n. bovienii of Bovien; named for P. Bovien, who first reported the presence of bacteria in the intestinal lumen of the $N$. bibionis infective stage) for bacteria symbiotic with $N$. bibionis (type strain, T228 [= University of Queensland Microbiology Collection UQM 2210]); and Xenorhabdus nematophilus subsp. poinarii (poi.nar'i.i. M.L. gen $\mathrm{n}$. poinarii of Poinar; named for G. O. Poinar, Jr., who has made major contributions to the understanding of the nematode-bacterial association and was involved in isolating the symbiont of $N$. glaseri) for bacteria symbiotic with $N$. glaseri (type strain, G1 [= UQM 2216]).

\section{ACKNOWLEDGMENTS}

The technical assistance of M. Stanfield, V. Patel, and J. Moss is appreciated. I also thank E. Dennis, Division of Plant Industry, Commonwealth Scientific and Industrial Research Organization, and G. Skyring, Fuel Geoscience Unit, Commonwealth Scientific and Industrial Research Organization, for determinations of the $G+C$ contents of DNAs and $R$. A. Bedding, M. A. Line, and R. J. Milner for criticism of the manuscript.

\section{LITERATURE CITED}

1. Akhurst, R. J. 1980 . Morphological and functional dimorphism in Xenorhabdus spp., bacteria symbiotically associated with the insect pathogenic nematodes Neoaplectana and Heterorhabditis. J. Gen. Microbiol. 121:303-309.

2. Akhurst, R. J., and R. A. Bedding. 1978. A simple crossbreeding technique to facilitate species determination in the genus Neoaplectana. Nematologica 24:328-330.

3. Anderson, L. R. 1930 . Peroxidase in relation to bacterial growth, with special reference to the influenza bacillus. J. Bacteriol. 20:371-379.

4. Bedding, R. A., and R. J. Akhurst. 1976. A simple technique for the detection of insect pathogenic rhabditid nematodes in soil. Nematologica 21:109-110.

5. Bovien, P. 1937. Some types of association between nematodes and insects. Vidensk. Medd. Dan. Naturhist. Foren. Khobenhavn 101:1-114.

6. Buchanan, R. E., and N. E. Gibbons (ed.). 1974. Bergey's manual of determinative bacteriology, 8th ed. The Williams \& Wilkins Co., Baltimore.

7. Cowan, S. T., and K. J. Steel. 1974. Manual of the identification of medical bacteria, 2nd ed. Cambridge University Press; Cambridge, England.

8. Difco Laboratories. 1962. Difco supplementary literature. Difco Laboratories, Detroit, Mich.

9. Dye, D. W. 1968. A taxonomic study of the genus Erwinia. I. The "Amylovora" group. N.Z. J. Sci. 11:590-607.

10. Hayes, P. R., T. A. McMeekin, and J. M. Shewan. 1978. The identification of gram negative yellow pigmented rods, p. 177-185. In F. A. Skinner and D. W. Lovelock (ed.), Identification methods for microbiologists, part B, 2nd ed. Academic Press, Inc., London.

11. Khan, $\dot{A}$., and W. M. Brooks. 1977. A chromogenic bioluminescent bacterium associated with the entomophilic nematode Chromonema heliothidis. J. Invertebr. Pathol. 29:253-261.

12. Khan, A., W. M. Brooks, and H. Mirschmann. 1976. Chromonema heliothidis n. gen., n. sp. (Steinernematidae, Nematoda), a parasite of Heliothis zea (Noctuidae, Lepidoptera) and other insects. J. Nematol. 8:159-168.

13. Moeller, V. 1955. Simplified tests for some amino acid decarboxylases and for the arginine dihydrolase system. Acta Pathol. Microbiol. Scand. 36:158-172.

14. Mracek, Z. 1977. Steinernema kraussei, a parasite of the body cavity of the sawfly, Cephaleia abietis in Czechoslovakia. J. Invertebr. Pathol. 30:87-94.

15. Poinar, G. O. 1975. Description and biology of a new insect parasitic rhabditoid, Heterorhabditis bacteriophora n. gen., n. sp. (Rhabditida, Heterorhabditidae n. fam.). Nematologica 21:463-470.

16. Poinar, G. O., and W. M. Brooks. 1977. Recovery of the entomogenous nematode, Neoaplectana glaseri Steiner from a native insect in North Carolina. I.R.C.S. Med. Sci. 5:473.

17. Poinar, G. O., and G. M. Thomas. 1965. A new bacterium, Achromobacter nematophilus sp. nov (Achromobacteriaceae: Eubacteriales), associated with a nematode. Int. Bull. Bacteriol. Nomencl. Taxon. 15:249-252.

18. Poinar, G. O., and G. M. Thomas. 1966. Significance of Achromobacter nematophilus Poinar and Thomas (Achromobacteriaceae: Eubacteriales) in the development of the nematode, DD136 (Neoaplectana sp., Steinernematidae). Parasitology 56:385-390.

19. Poinar, G. O., G. M. Thomas, and R. Hess. 1977. Characteristics of the specific bacterium associated with Heterorhabditis bacteriophora (Heterorhabditidae: Rhabditida). Nematologica 23:97-102.

20. Schaeffer, E. 1961. The use of the cytochromoxidase reaction for detecting Pseudomonas aeruginosa in mixed cultures. Roentgen Lab. Prax. 14:142-146.

21. Schildkraut, C. L., J. Marmur, and P. Doty. 1962. Determination of the base composition of deoxyribonucleic acid from its buoyant density in CsCl. J. Mol. Biol. 4:430-443.

22. Shaw, C., and P. H. Clarke. 1955 . Biochemical classification of Proteus and Providence cultures. J. Gen. Microbiol. 13:155-161.

23. Sierra, G. 1957. A simple method for the detection of lipolytic activity of micro-organisms and some observations on the influence of the contact between cells and fatty substances. Antonie van Leeuwenhoek J. Microbiol. Serol. 23:15-22.

24. Stanuszek, S. 1974. Neoaplectana feltiae complex (Nematoda: Rhabditoidea, Steinernematidae), its taxonomic position within the genus Neoaplectana and intraspecific structure. Zesz. Probl. Postepow Nauk Roln. 154:331359.

25. Thomas, G. M., and G. O. Poinar. 1979. Xenorhabdus gen. nov., a genus of entomopathogenic nematophilic bacteria of the family Enterobacteriaceae. Int. J. Syst. Bacteriol. 29:352-360. 